„Bohemistyka” 2021, nr 1, ISSN 1642-9893

Наталия Е. БОЕВА

DOI: $10.14746 / b o .2021 .1 .5$

Санкт-Петербургский государственный университет

\section{Имя собственное в составе современных белорусских пословиц на фоне чешских паремий"}

Keywords: Belorussian language, Czech language, proper name, paremiological minimum, proverb

Ключевые слова: белорусский язык, чешский язык, имя собственное, паремиологический минимум, пословица

\section{Abstract}

The proper name is an important object of analysis when comparing proverbs on the material of different languages and cultures. The object of this research is Czech-Belorussian proverbial parallels with a proper name component

Some studies have been devoted to the question of proper names in the composition of Czech and Belorussian paremias and their role in the formation of stereotypes, but this work examines this issue in a new aspect.

The aim of the research is to compare proper names in modern Czech and Belorussian proverbs; identification of cultural connotations of proper names in paremias, as well as identification of lacunae in the Belorussian paremiological fund of modern active proverbs.

Имя собственное - важный объект анализа при сравнении пословиц на материале разных языков и культур. Объектом исследования являются чешско-белорусские пословичные параллели с компонентом-именем собственным.

Некоторые исследования посвящены вопросу об именах собственных в составе чешских и белорусских паремий и их роли в формировании стереотипов, но в данной работе этот вопрос рассматривается в новом аспекте.

Цель исследования - сравнить имена собственные в современных чешских и белорусских пословицах; выявить культурные коннотации имен соб-

* Исследование выполнено при финансовой поддержке РФФИ в рамках научного проекта № 20-012-00105. Acknowledgments: The research was funded by RFBR. project number 20-012-00105. ственных в паремиях, а также выявить лакуны в белорусском Паремиологическом фонде современных активных пословиц.

\section{1. Оним как предмет изучения в разных аспектах языка} и культуры

Паремии с ономастическим компонентом представляют особый интерес, поскольку «имя собственное в паремиях и идиомах преодолевает своё назначение в языке и приобретает функцию знака «языка» культуры - символа, эталона, стереотипа и т.д.» (Ковшова 2019а, с. 147). Имя собственное находится в центре внимания исследователей языка и культуры. Наибольшее внимание уделяется изучению онимов в художественном тексте, анализируются особенности их употребления в поэтическом и прозаических текстах, в заглавиях художественных произведений. В своей статье «Онім-этнонім Іван у творах мастацкай літаратуры і фальклоры» [Оним-этноним Иван в произведениях художественной литературы и фольклора] В. В. Шур даёт подробный историко-этимологический анализ имени собственному Иван, приводит яркие примеры использования этого имени в русской, белорусской и украинской художественной литературе.

В лексикологии, фразеологии и паремиологии имя собственное исследуется, главным образом, в историко-этимологическом, структурно-семантическом и сопоставительном аспекте, причем особое внимание уделяется проблематике библейских имён. Так в кратком словаре-справочнике «Библеизмы в современной русской речи» В. М. Мокиенко описываются наиболее употребительные библеизмы с «точно паспортизированным источником» (Мокиенко 2017, с. 7). В 2009 году польский исследователь Т. Szutkowski в статье Jednostki paremiologiczne z komponentem onomastycznym w praktyce leksykograficznej даёт лексикографическое описание паремий, содержащих ономастический компонент. Автор считает, что необходимо составить специальный двуязычный словарь, который параллельно с объяснением 
значений паремии будет содержать исчерпывающую лингвистическую и культурологическую характеристику ономастических компонентов (Szutkowski 2009, с. 33). Значительным вкладом в изучение имени собственного в аспекте лексикологии является Словарь собственных имён в русских загадках, пословищах и идиомах М. Л. Ковшовой. Словарь представляет собой

[...] новаторский лексикографический продукт, в основу которого положен лингвокультурологический принцип описания паремий и идиом, как знаков, способных хранить и передавать из поколения в поколение культурную информацию, в том числе с помощью такого показательного компонента, как имя собственное» (Ковшова 2019b, s. 2).

Имя собственное является важным объектом анализа при сравнении фразеологических и паремиологических единиц на материале разных языков и культур. По мнению белорусского исследователя А. Яршэвича,

[...] у лексічным фоне ўласнага імені ўтрымліваецца багаты краязнаўчы матэрыял. Гэта падводзіць да высновы, што ўласнае імя, называючы людзей, 3'яўляецца адным 3 важнейшых сродкаў для выяўлення тых нацыянальнакультурных асаблівасцей, што дазваляюць змадэляваць партрэт нацыі, паказаць спецыфіку функцыянавання чалавека ў грамадстве, яго непарыўную сувязь з соцыумам, а таксама ўплыў грамадства на жыццё чалавека. Своеасаблівасць ўласнага імені як кампанента мовы і культуры дыктуе неабходнасць дасканалага вывучэння асблівасцей яго функцыянавання ў складзе фразеалагічных адзінак і дае падставы для вывучэння ўстойлівых моўных зваротаў 3 кампанентам-антрапонімам у асобную группу» [в лексическом фоне имени собственного содержится богатый страноведческий материал. Из этого следует, что имя собственное, называя людей, является одним из важнейших средств для выявления национально-культурных особенностей, которые позволяют смоделировать портрет нации, показать специфику функционирования человека в обществе, его непрерывную связь с социумом, а также влияние общества на жизнь человека. Особенность имени собственного как компонента языка и культуры диктует необходимость досконального изучения особенностей его функционирования в составе фразеологических единиц и даёт основания для выделения устойчивых языковых словосочетаний с компонентом-антропонимом в особую группу] (Яршэвіч 2007, с. 252).
Важным вкладом в изучение паремиологических единиц на материале восточнославянских языков является «Электронный словарь современных активных восточнославянских пословиц», создаваемый в Санкт-Петербургском университете на кафедре славянской филологии под руководством профессора М. Ю. Котовой (Kotova, Mushchinskaya, Sergienko 2020).

\section{2. Цель исследования}

Основной целью данного исследования является сопоставительный анализ современных, активно используемых чешских и белорусских пословиц, в составе которых имеется имя собственное. Выделенные пословицы позволят выявить эквивалентность в паремийном ономастиконе двух языков, а также позволят исследовать некоторые стереотипы, существующие в белорусском языке, и их восприятие чехами.

\section{3. Задачи исследования}

Для достижения поставленной цели необходимо: 1) вычленить пословицы с именами собственными в белорусском и чешском языках; 2) зафиксировать онимы, которые характерны для обеих лингвокультур.

\section{4. Вопросы исследования}

В этом исследовании планируется ответить на следующие вопросы: 1) Какие имена собственные используются в современных пословицах чешского и белорусского языков? 2) Существуют ли чешские и белорусские пословицы с компонентомонимом, имеющие полную эквивалентность?

\section{5. Методы исследования}

В исследовании использованы следующие методы: метод сопоставительного паремиологического анализа; метод лингвокультурологического анализа; метод социолингвистического паремиологического эксперимента. 


\section{6. Имя собственное в чешско-белорусских параллелях}

Предметом нашего внимания являются паремии с именем собственным на материале белорусского и чешского языков. Чтобы достичь поставленной цели, необходимо исследовать стереотипы, которые существуют в белорусском языке. Под стереотипом, вслед за В. А. Масловой, понимается «такое явление языка и речи, такой стабилизирующий фактор, который позволяет, с одной стороны, хранить и транспонировать некоторые доминантные составляющие данной культуры, а с другой - проявить себя среди «своих» и одновременно опознать «своего» (Маслова 2010, с. 110). В качестве источника материала был использован словарь Východoslovanská př́sloví a pořekadla v pohledu od češtiny Э. Мргачовой и ее соавторов (Mrhačová 2010). Данный словарь представляет наиболее употребительные чешские пословицы и поговорки, а также их русский, белорусский и украинский эквивалент. Всего словарь насчитывает 752 пословицы и поговорки. В словаре 8 чешских пословиц имеет в своем составе имя собственное, из них два топонима Praha и Řím, остальные - антропонимы: Anna, Jeniček, Katka, Mařen$k a$, Mohamed. Белорусских эквивалентов с онимом - 9 пословиц. Из них топонимы: Вільня, Кіег̆, Масква, Рым и антропонимы: Фама, Кузьма, Хомка, Ярома /Яромка, Магамед, Варвара, Ганна, Грылика.

Проведенный анализ выявил две пары пословичных параллелей, которые имееют полную эквивалентность в белорусском и чешском языках: чеш. Když nejde hora $k$ Mohamedovi, musí jít Mohamed $k$ hoře - бел. Калі гара не ідзе да Магамета, mо Магамет ідзе да гары (Mrhačová 2017, № 315) и чеш. V̌̌echny cesty vedou do Ř́ma - бел. Усе дарогі вядуцьь у Pbым (Mrhačová 2017, № 711).

Следующие две пословицы не являются полными эквивалентами по форме, но имеют одинаковое значение: чеш. Svatá Anna - chladno zrána - бел. Прызапашвае да Ганны зіма халодныя ранішнікі (Mrhačová 2017, № 644). Здесь мы видим характерное для паремий использование народных названий праздников. Церковные праздники имели большое значение в жизни крестьянина. Названия этих дней входили в пословицы, поговорки, обозначая определенное время в году.

В состав следующих паремий входят топонимы Macква/Praha: чеш. Ani Praha nebyla vystavěna za rok - бел. Маскву не адpaзу nастроілі (Mrhačová 2017, № 2)

По словам В. М. Чарапко,

[...] тапонімы з'яўляюцца носьбітамі звестак пра традыцыі, звычаі, светапогляд народа, пра гістарычныя і сацыяльныя асаблівасці краіны» [топонимы являются носителями информации о традициях, привычках, мировозрении народа, о его исторических и социальных особенностях] (Чарапко 2008, с. 72).

Следующие белорусские пословицы с омонимом не имеют чешского эквивалента, в состав которого входит имя собственное. Использование имён собственных Варвара, Вільня, Грыика, Кузьма, Фама, Хомка, Ярома / Яромка, в белорусских пословицах обусловлено разными причинами. В одном случае имя собственное в паремиях служит для создания рифмы, придания мелодичности, например: чеш. Trp, kozáče, budeš atamanem бел. Цярпі, Грышка, карчма блізка (Mrhačová 2017, № 669); чеш. Trpělivost přináši růže - бел. Круuฺi жорны пільна, то й будзе Вільня (Mrhačová 2017, № 670).

Говоря о роли антропонима в пословице, О.Е. Фролова вводит понятие типового антропонима. Типовой антропоним -

[...] наиболее распространенный и известный антропоним, который ассоциируется у носителей языка и культуры с классом объектов, или же эталонным представителем класса» (Фролова 2007, с. 246).

Нельзя не отметить, что в паремийном ономастиконе функционируют имена, имеющие дополнительное оценочное значение и обладающие ассоциативным полем. Так имя Варвара в белорусском онимастиконе ассоциируется с чрезмерным любопытством, что нашло отражение в паремии: бел. Цікаўнай Варвары нос на кірмашы адарвалі- чеш. Ne bud' zvědavý budeš brzo 
starý (Mrhačová 2017, № 417). В другом случае имя собственное имеет обобщающее значение, его легко можно заменить на другое имя, не потеряв при этом значение пословицы. В этом легко убедиться на следующем примере: бел. Я яму пра Фаму/ /Кузьму/Хомку, а ён мне пра Ярому/Яромку; чеш. Já o voze, ty o koze (Mrhačová 2017, № 160). Следующие чешские паремии с омонимом не имеют белорусского эквивалента с именем собственным: чеш. Jaká matka, taková dcerka/Katka - бел. Якая клёпка, такая бочка, якая мачі ,такая дочка (Mrhačová 2017, № 216); чеш. Jednomu se líbi matka, druhému zas Katka - бел. Кожнаму сваё дзіия міла/Дзіиятка хочь і крыва, ды баџьку з маткаю міла (Mrhačová 2017, № 216); чеш. Každá Mařenka chce mít svého Jenička - бел. Кожная пачвара мае сваю пару (Mrhačová 2017, № 199).

\section{7. Имя собственное в чешской паремиографии}

Безусловно, ни белорусский, ни чешский паремийный ономастикон не ограничивается только упомянутыми в данной работе паремиями. Количество пословиц с именем собственным гораздо больше. Обратимся к словарю Д. Биттнеровой и Ф. Шиндлера Česká př́sloví. Soudobý stav konce 20. století.

Словарь был опубликован в 1997 году и стал первым крупномасштабным паремиологическим трудом со времен Ф. Л. Челаковского. Основным источником сборника послужил словарь Ф.Л. Челаковского Mudrosloví národu slovanského ve př́slovich, который дополнили два ранее неопубликованных собрания пословиц XX в. - собрание Й. Спилки (50-70-е гг. XX в.) и собрание Д. Биттнеровой (cep. 80-х гг. XX в.). Также в словарь вошли чешские пословицы, зафиксированные Ф. Шиндлером в конце $80-x$ - начале 90-х годов XX в., ранее публиковавшиеся в его диссертации. Словарь Д. Биттнеровой и Ф. Шиндлера стал первой попыткой выявления паремиологического минимума современного чешского языка (Сергиенко 2015, Sergienko 2019).

В словаре насчитывается около 20 пословиц с онимами: Adam, Anička/Aninka, Bara, Dalibor, Eva, Franta/Francek, Jan/Ja-
nek/Jeniček, Jano/Janko, Katka, Kuba/Kubiček, Marie/Marija/Mařna/Mařka, Mohamed, Pavel, Pepićěk, Petr, Šavel, Tomáš.

К нашему исследованию были подключены еще два источника: Русско-славянский словарь пословии М. Ю. Котовой и Тетради паремиографа. Выпуск 2. Чешские пословичные параллели русских пословиц паремиологического минимума М. Ю. Котовой и О. С. Сергиенко. Русско-славянский словарь пословии М. Ю. Котовой (далее - Котова 2000) был опубликован в 2000 году в Санкт-Петербурге. Основу словаря составляют 500 русских пословиц из паремиологического минимума Г.Л. Пермякова. К этим пословицам автором были подобраны соответствия из семи славянских языков и английского языка. Таким образом в состав вошли 652 белорусские пословицы, 628 болгарских, 465 польских, 670 сербских, 568 словацких, 826 украинских, 508 чешских и 472 английские пословицы (Котова 2010, с. 87). Следует подчеркнуть, что словарь является первым опытом подбора соответствий на основе предварительного исследования употребительности пословиц в соответствующих языках, т.е. на основе нормативности использования пословиц. Тетради паремиографа. Выпуск 2. Чешские пословичные параллели русских пословиц паремиологического минимума (далее - Тетради паремиографа №2) М. Ю. Котовой и О. С. Сергиенко являются результатом второй части исследования профессора М. Ю. Котовой. В пособии даны чешско-русские пословичные параллели и чешские текстовые иллюстрации к ним, выбранные из разных источников, включая интернет. Следует уточнить, что в Тетрадяx паремиографа 2 представлены не все современные употребительные чешские пословицы, а только те, которые являются параллелями употребительных русских пословиц, т.е. паремиологического минимума Г. Л. Пермякова (Котова, Сергиенко 2013, с. 3). В пособии представлены результаты паремиологического социолингвистического эксперимента, который был проведен в 2003-2004 гг. Несколько слов о паремиологическом социолингвистическом эксперименте: в основе эксперимента лежит 
100 анкет с пословицами, пословицы даны не полностью, дана лишь первая часть пословицы, информанты (носители языка) должны закончить пословицу, написать свой вариант. Далее была проведена компьютерная обработка заполненных анкет, найдены иллюстрации к пословицам и выявлены наиболее употребительные пословицы. Эксперимент был проведен на семи славянских языках, в том числе на чешском и белорусском языках, о белорусском языке речь пойдёт ниже.

В этих двух источниках методом сплошной выборки были выявлены следующие пословицы с именами собственными:

Byl v Ř́mě, a papeže neviděl - бел. /букв. У Рыме быў,а папы не бачыў/

Jaká matka, taká Katka - бел. Якая матка, такое і дзіцятка.

Když nejde hora k Mohamedovi, musí Mohamed k hoře - бел. Калі гара не ідзе да Магамета, Магамет ідзе да гары.

Petr na Pavla, a Pavel na Petra/ Petr na Pavla, a Pavel na Havla/ Petr na Pavla, a bratr na bratra / Petr na Pavla, a Pavel na bránu - бел. Я яму пра абразы, ён мне пра гарбузы.

Таким образом, исследовав четыре паремиологических источника (общее количество 6960 паремийных единиц): Východoslovanská př́sloví a pořekadla v pohledu od češtiny (752 паремии), Česká prísloví. Soudobý stav konce 20. století (около 5700 паремий), Русско-славянский словарь пословии (508 чешских паремий), Тетради паремиографа. Выпуск 2. Чешские пословичные параллели русских пословии паремиологического минимума, методом сплошной выборки было выделено около 30 пословиц с именем собственным, в которых: 1) наиболее активными являются онимы: Adam, Annal Anička/Aninka, Bara, Dalibor, Eva, Franta/Francek, Jan/Janek/Jeníček, Jano/Janko, Katka, Kuba/Kubiček, Marie/ /Marija/Mařena/ Mařenka /Mařka, Mohamed, Pavel, Pepičěk, Petr, Praha, Řim, Šavel, Tomáš; 2) две пословицы отражены во всех рассматриваемых нами источниках Když nejde hora $k$ Mohamedovi, musí Mohamed k hoře и Jaká matka, taková/ taká dcerka/Kat$k a$.

\section{8. Имя собственное в белорусской паремиографии}

Белорусская паремиография и паремиология имеет богатую историю. Ее создавала целая плеяда выдающихся славистовязыковедов, фольклористов, этнографов, паремиологов. У ее истоков стоит выдающийся лингвист, автор первых сборников белорусских пословиц Иван Иванович Носович (1788-1877), его книга Белорусские пословицы и поговорки впервые была напечатана в 1852 году в Санкт-Петербурге, а затем вышел двухтомник Сборник белорусских пословиц (1867; 1869). Для белорусского языкознания важное значение имеют фундаментальные лингвистические труды выдающегося ученого, академика Евфимия Федоровича Карского (1861-1931). Они имеют огромное научное и практическое значение для каждого, кто занимается исследованием и изучением белорусского языка. Особенно большое значение для белорусского языкознания имеет многотомный труд «Белорусы». Третий том «Белорусов» (1916) посвящен белорусской литературе и содержит Очерки словесности белорусского племени. В первом выпуске, посвященном народной поэзии, автор отдельное внимание уделяет пословицам и поговоркам. Академик Карский говорит, что пословицы являются одним из древнейших видов народной словесности,

[...] пословицами старики научают молодежь доброй нравственности, пословицами они преследуют пороки и слабости, к ним они обращаются при утешении в несчастии и печали, есть ряд пословиц насмешливо-шутливых, которыми они развлекают себя в своей однообразно-монотонной жизни (Карский, 1916, c. 388).

К нашему исследованию были подключены современные словари белорусских пословиц. Слоўнік беларускіх прыказак И. Я. Лепешева и М. А. Яколцевич (2002) описывает 1500 наиболее употребительных пословиц и насчитывает около 60 паремий с именем собственным-антропонимами и топонимами, например: Базыль, Барыс, Варвара, Гаўрыла, Гірша, Грыгор, Грышка, Змічер, Зося, Іван, Ілля, Іспас, Кузьма, Магамет, Маг- 
далена, Макавей, Макар, Маруся, Мікіта, Мікола, Насия, Пакроў, Паланея, Паниялей, Пётр, Платон, Пятро/Пятрок, Пятроўна, Пятрусь, Сайка, Сенька, Сідар, Сияпан, Фама, Халімон, Хомка, Хоўра, Юрый, Ямеля, Янка, Ярома, Яўмень, Беларусь, Кіеў, Масква, Нёман, Полаик.

Русско-славянский словарь пословии М. Ю. Котовой и Тетради паремиографа. Выпуск 5. Белорусские пословичные параллели русских пословии паремиологического минимума М. Ю. Котовой и Н. Е. Боевой насчитывают 652 белорусские пословицы и включают около 7 пословиц с именем собственным, например:

А Васька слухае ды есць - чеш. сp. Jedním uchem tam, druhým ven.

Калі гара не ідзе да Магамета, Магамет ідзе да гары - чеш. Když nejde hora $\mathrm{k}$ Mohamedovi, musí jít Mohamed $\mathrm{k}$ hoře.

Масква слязам не верыць - чеш. ср.ФЕ: Plakat nad cibilí (nad rozlitým mlékem). Не адразу Вільню будавалі - чеш. Ani Praha nebyla vystavěna za rok.

Не за дзень Вільня будавалася (ставілася) - чеш. Ani Praha nebyla vystavěna za rok.

Не на Юрку шапка - чеш.сp.Za málo peněz málo muziky.

Па Саўку (Хомку, Юрку)шапка - чеш.сp.Za málo peněz málo muzik.

Цярпі, Грышка, карчма блізка - чеш.Trp, kozače, budeš atamanem.

Язык да Вільні давядзе - чеш.cp.Líná huba( ruka) holé( hotové) neštěstí.

Язык да Кіева давядзе - чеш.cp.Líná huba( ruka) holé( hotové) neštěstí.

Таким образом, было проанализировано около 2900 белорусских пословиц из четырех источников, методом сплошной выборки было выделено около 80 паремиологических единиц, в состав которых входит имя собственное и были сделаны следующие выводы:

1) наиболее активными онимами в современных белорусских паремиях являются следующие: Базыль, Барыс, Беларусь, Варвара, Вільня, Ганна, Гаўрыла, Гіриа, Грыгор, Грышка, Зміиер, Зося, Іван, Ілля, Іспас, Кіеў, Кузьма, Магамет, Магдалена, Макавей, Макар, Маруся, Масква, Мікіта, Мікола, Насия, Нёман, Пакроў, Паланея, Паниялей, Пётр, Платон, Полаик,
Пятро/Пятрок, Пятроўна, Пятрусь, Рым, Сайка, Сенька, Сідар, Сияпан, Фама, Халімон, Хомка, Хоўра, Юрый, Ямеля, Янка, ЯромаІЯромка, Яўмень;

2) две паремии присутствуют во всех рассматриваемых нами источниках белорусской паремиологии: Калі гара не ідзе да Магамета, Магамет ідзе да гары и Маскву не адразу пастроілі / Не адразу Вільню будавалі / Не за дзень Вільня будавалася (ставілася).

При сопоставлении результатов, полученных в результате исследования пословичных единиц с именем собственным в чешской и белорусской паремиологии, было обнаружено, что в чешском паремийном фонде паремии с ономастическим компонентом составляют менее $1 \%$, в белорусском около $2,6 \%$. Из 30 чешских пословиц с онимом следующие имеют пословичную параллель с онимом в белорусском языке:

чеш. Když nejde hora k Mohamedovi, musí jít Mohamed k hoře - бел. Калі гара не ідзе да Магамета, то Магамет ідзе да гары.

чеш. V̌̌echny cesty vedou do Ř́ma - бел. Усе дарогі вядуць у Рым.

чеш. Svatá Anna - chladno zrána - бел. Прызапашвае да Ганны зіма халодныя ранішнікі.

чеш. Ani Praha nebyla vystavěna za rok - бел. Маскву не адразу пастроілі.

В остальных случаях наблюдается отсутствие онима в пословице, например:

чеш. Jaká matka, taká Katka - бел. Якая матка, такое і дзіцятка.

чеш. Petr na Pavla, a Pavel na Havla - бел. Я яму пра абразы, ён мне пра гарбузы $u \partial p$.

Обратимся к белорусским паремиям с компонентом-онимом. Из 80 белорусских паремий оним в чешской паремии имеют следующие:

бел. Калі гара не ідзе да Магамета, Магамет ідзе да гары - чеш. Když nejde hora k Mohamedovi, musí jít Mohamed k hoře. 
бел. Не адразу Вільню будавалі - чеш. Ani Praha nebyla vystavěna za rok.

В остальных случаях не обнаружены онимы в пословице, например:

бел. А Васька слухае ды есць - чеш. ср. Jedním uchem tam, druhým ven. бел. Па Саўку (Хомку, Юрку)шапка - чеш. $c p$. Za málo peněz málo muzik. бел. Цярпі, Грышка, карчма блізка - чеш. Trp, kozače, budeš atamanem и др.

\section{Вслед за В. А. Масловой мы считаем:}

[...] важную роль в формировании стереотипов играет частота встречаемости определенных объектов, явлений в жизни людей, нередко выражающаяся в более продолжительных человеческих контактах именно с данными объектами по сравнению с другими, что и приводит к стереотипизации подобных объектов (Маслова 2010, с. 111).

Чешской пословице Ani Praha nebyla vystavěna za rok в белорусской паремиологии соответствует несколько вариантов:

Маскву не адразу пастроілі (Mrhačová 2017, № 2; Лепешаў, Якалцэвіч 2002, c. 260)

Не адразу Вільню будавалі / Не за дзень Вільня будавалася (ставілася) (Котова 2000, № 247; Котова, Боева 2019, с. 154, 163; Санько 1991, № 0203; Янкоўскі 1992 , с. 223).

Не адразу Кіеў будован (Аксамітаў 2002, с. 154).

Как видно из приведённых примеров, в составе пословицы участвуют три топонима (Масква, Вільня, Кіег̆). Эти топонимы входят в состав и других паремий:

Язык да Вільні/Кіева давядзе (Котова 2000, № 493; Котова, Боева 2019, с. 294) Рабі пільна, то і будзе Вільня (Янкоўскі 1992, с. 95)

Круці жорны пільна, то й будзе Вільня (Mrhačová 2017, № 670).

Таким образом Масква, Вільня, Кіеў являются типичными именами собственными в паремиологическом фонде белорусского языка.

\section{9. Выводы}

Итак, в результате нашего исследования было проанализировано 9864 пословиц в чешской (около 6960) и белорусской паремиологии (около 2900); были вычленены имена собственные, характерные для каждого языка; зафиксированы онимы, которые характерны для обеих лингвокультур. На основе этого можно сделать следующие выводы:

- полную эквивалентность имеет одна пословица: Když nejde hora $k$ Mohamedovi, musí jít Mohamed $k$ hoře - бел. Калі гара не ідзе да Магамета, то Магамет ідзе да гары;

- следующие пословицы имеют одинаковое значение: Ani Praha nebyla vystavěna za rok - бел. Маскву не адразу пастроілі / Не адразу Вільню будавалі / Не за дзень Вільня будавалася (ставілася); Svatá Anna - chladno zrána - бел. Прызапашвае да Ганны зіма халодныя ранішнікі; V̌̌echny cesty vedou do Ří$m a$ - бел. Усе дарогі вядуць у Pым (в рассматриваемых нами источниках последние две пословицы зафиксированы только в словаре Э. Мргачовой);

- типичными топонимами в белорусской паремиологии являются Масква, Вільня, Кіеў;

- в чешском паремийном фонде пословицы с ономастическим компонентом составляют менее $1 \%$ от общего количества рассмотренных пословиц, в белорусском - около 2,6 \%.

\section{Литература}

B it t n e rová D., S c hi ind le r F., 2002, Česká př́sloví Soudobý stav konce 20. stoleti. Praha: Karolinum.

K ot o v a M. Yu., Mushchinskaya V. V., Sergienko O. S., 2020, East Slavonic proverbs with ethnonyms in the electronic dictionary of current proverbs. In: The European Proceedings of Social and Behavioral Sciences EpSBS WUT 2020. 10th International Conference "Word, Utterance, Text: Cognitive, Pragmatic and Cultural Aspects", p. 748-757.

Mrha čová E. a kol., 2017, Východoslovanská př́isloví a pořekadla v pohledu od češtiny. Ostrava: Filozofická fakulta Ostravské univerzity v Ostravě.

Sergienko O. S., 2019, Main trends of the current research of Czech paremiology. "Bohemistyka", nr 1, s. 49-70. 
S z u t k o w s k i T., 2009, Jednostki paremiologiczne z komponentem onomastycznym $w$ praktyce leksykograficznej [в:] Проблемы истории, филологии, культуры, №2, Москва-Магнитогорск-Новосибирск, с. 33-37.

А к с а м і т а ў А., 2002, Прыказкі і прымаўкі. Мінск: Беларусская навука.

К а р с к и й Е. Ф.,1916, Белорусы, т.3, Москва: Типо-литография Т-ва И. Н. Кушнеревъ и $\mathrm{K}^{\circ}$.

Ко в шо в а М. Л., 2019а, Лингвокультурологический анализ идиом,загадок, пословии и поговорок. Антропонимический код культуры. Москва: Издательство ЛЕНАД.

Ко в шо в а М. Л., 2019b, Словарь собственных имён в русских загадках, пословииах, поговорках и идиомах. Москва : Издательство ЛЕНАД

К о т о в а М. Ю., 2000, Русско-славянский словарь пословии с английскими соответствиями. СПб.: Издательство Санкт-Петербургского университета.

Ко т о в а М. Ю., 2010, Лекичии по сопоставительной славянской паремиологии. Учебное пособие для магистрантов. Санкт-Петербург: Филологический факультет Санкт-Петербургского университета.

К о т о в а М. Ю., Б о е в а Н. Е., 2019, Тетради паремиографа. Bып. 5. Белорусские пословичные параллели русских послович паремиологического минимума: учебное пособие для студентов. Санкт-Петербург: Издательство ВВМ.

Ко то ва М. Ю., С ер г и ен ко О. С., 2013, Тетради паремиографа. Bып. 2. Чешские пословичные параллели русских пословии паремиологического минимума: учебное пособие для студентов. Санкт-Петербург: Филологический факультет Санкт-Петербургского университета.

Л е пе ш аў I. Я., Яка лцэв іч М. А., 2002, Слоўнік беларускіх прыказак. Минск: Беларусская навука.

М аслова В. А., 2010, Лингвокультурология: учебное пособие для студентов. Москва: Издательский цент Академия.

М о к и е н ко В.М.2017, Библеизмы в современной русской речи. Как их правильно понимать и употреблять. Москва: Центрполиграф.

Н о с о в ич И.И., 1874, Сборник белорусских пословии. Санкт-Петербург. Online: https://zapadrus.su/bibli/etnobib/140-q-q-1874.html.

С анько 3., 1991, Малы Расейска-Беларускі слоўнік прыказак,прымавак і фразем. Online: https://szlachta.io.ua/s427092/zmicer_sanko_maly_rasey ska-belaruski_slonik_prykazak_prymavak_i_frazem.

С ер г и е н ко О.С., 2015, Нормативность и вариантность чешских и словацких пословии [монография]. Санкт-Петербург: Санкт-Петербургский университет.
Ф р ол о в а О. Е.,2007, Мир, стоящий за текстом: Референииальные механизмы пословицьь, анекдота, волшебной сказки и авторского повествовательного художественного текста. Москва: Издательство ЛКИ.

Ч а р а п к о В.М., 2008, Тапонімы $\check{y}$ «Сборнике белорусских пословии» I. I. Насовіча $i$ «Пословицах русского народа» У. І.Даля [в:] Спадчына Івана Насовіча і беларускае мовазнаўства [Текст]. Матэрыялы навуковых чытанняў, прысвечаных 220-годдзю з дня нараджэння Івана Іванавіча Насовіча, 18.02.2008 г., Мінск.

Шур В. В., 2010, Онім-этнонім Іван у творах мастаикай літаратуры і фальклоры, ,Полымя” [Мінск] №12, с. 123-131.

Я н ко ў ск і Ф.,1992, Беларускія прыказкі,прымаўкі, фразеалагізмы. Мінск: Навука і тэхніка.

Я р ш э в і ч А. Л., 2007, Функиьлянаванне ўласных імёнаў у складзе беларускіх фразеалагічных адзінак [в:] Мова - Літаратура - Культура [Текст]. Міжнародная V навук. канф.,Мінск, 16-17 лістап. 2006 г., Мінск: Издательство Права і эканоміка, с. 251-253. 